\title{
RISK ASSESSMENT IN THE ISLAMIC CLOTHING SUPPLY CHAIN MANAGEMENT USING BEST-WORST METHOD
}

\author{
Eli Sumarliah* \\ *Corresponding Author \\ School of Economics and Management, University of Science and Technology Beijing, No.30,Xueyuan Road,Haidian \\ District, Beijing, China.b20170639@xs.ustb.edu.cn,2761514566@@qq.com
}

\begin{abstract}
Almost a quarter of the world's population is Muslim; thus, the Islamic clothing industry is an important global business segment. Despite the immense and emerging market size of the Islamic clothing industry worldwide, there is still a scarcity of research concentrated on Islamic clothing products in the subject of Halal supply chain risk management. No previous studies comprehensively examine and provide a systematic agenda to alleviate risks in the Islamic clothing supply chain (ICSC) management. The study presents the BestWorst method to examine the ICSC's risks. The research applied the sample size based on the table advised by Krejcie and Morgan (1970), signifying that with a total population of 145, this study's sample size was 105 specialists (with a response rate of 53.3\%). Through the specialists' points of view and an in-depth literature review, the study identifies critical risks in the ICSC and ranks them based on their importance. The proposed findings support corporate leaders, researchers, and policymakers, focusing on the Islamic clothing business, to continually examine the risks significantly influencing their ICSCs. Firms can concentrate on the most significant supply chain risks and build effective mitigation strategies.
\end{abstract}

Keywords: Islamic clothing industry, emerging market, Halal supply chain, risk management; Best-Worst method, risk mitigation strategies

Received

Revised

Accepted

Published

February 27, 2021

March 8, 2021

March 23, 2021

March 31, 2021

\section{INTRODUCTION}

Nearly a quarter of the world's population is Muslim (which counts $24 \%$ of the worlds' population or 1.9 billion, (Religion by country 2021); thus, the Islamic clothing industry is an important global business segment. Islamic clothing business volume is rising internationally: Muslim expenditure on clothing products (clothes and shoes) was projected to achieve \$402 billion in 2024 from the initial \$283 billion in 2018 (DinarStandard, 2020). Islamic clothing products are not only produced by local industries in Muslim majority countries; they are also interestingly manufactured by the world's famous luxury brands as the top key players, e.g., Tommy Hilfiger, Oscar de la Renta, Dolce and Gabbana, Zara Chanel (Sumarliah, Li, Wang, Mooda, \& Sackey, 2021). Apart from these facts, the upsurge of Muslim global clothing business has brought a challenging task for the companies and their business partners to guarantee and maintain the implementation of Halal/Islamic principles along the whole stages of the Islamic clothing supply chain (ICSC), from the beginning/resourcing point until the end/consumer point (Sumarliah et al., 2021).

The introduction of the information technology-grounded comprehension market and growth in discretionary spending has generated a request for services and goods that have better quality and safety. Industries have been pushed to discover ways to fulfill these demands, which can gratify contemporary customers. It took Halal services and goods in the modern industry sphere and developed as a novel standard for guaranteeing safety and quality (Khan and Haleem, 2016). The conventional business situation depicted Halal/Islamic 
products as consumer goods for a specific belief of the populace. Nevertheless, Halal is a worldwide principle that influences every aspect of human life, such as consumption, behavior, ways of pays, and relations (Alzeer, Rieder, \& Hadeed, 2018). The word "Halal" literally implies legitimate or allowable in Islamic decree, and every consumer product for the Islamic population is supposed to be Halal. Halal is not restricted to foods but including other Islamic products such as clothing products (Sumarliah, Li, \& Wang, 2020). Islamic clothing products signify all garments, footwear, and accessories in line with the Islamic dress code, not only in design, which should show modesty but also in materials that should be Halal (Sumarliah et al., 2021).

Nonetheless, literature proves that Halal principles are outside the consumption obligations and more apparent based on the Halal supply chain. The word "tayyib" applied to supplement 'Halal' signifies that Halal products (including clothes) must have a good quality such as clean, pure, hygienic, uncontaminated, non-toxic, non-hazardous (Neio Demirci, Soon, \& Wallace, 2016). Mainly, tayyib describes that Halal goods are hygienic, free from haram/unlawful ingredients, originated from lawful resources, not triggering discomfort and suffering to persons who consume or produce it. In the context of Islamic clothing, Halal garments are clean, free from unlawful materials such as pigskin/hair and other unlawful animal parts, not causing skin irritation and skin cancer (Sumarliah et al., 2021). The notion of tayyib is also associated with "ethical consumption" (here: of clothing), "sustainable spending activities," "ecological protection," and "fair trade" (Khan, Haleem, \& Khan, 2021). The Halal manufacturing process removes components harmful to people's well-being and the ecosystem (Alzeer, Rieder, \& Hadeed, 2018). For example, when burkini (a type of Islamic swimsuit) was manufactured and introduced, many non-Muslims purchased it because they know that this type of clothing is safe to wear and even can protect them from skin cancer (Dumas, 2016). Thus, the Islamic clothes' production process should always consider human health and the environment to maintain brand image.

Furthermore, Halal businesses must ensure Halal integrity from farm to wardrobe (Sumarliah et al., 2021). It needs a supply chain as a process that incorporates resourcing, manufacturing, packaging, warehousing, transporting, retailing until final products reach consumers. Hence, ICSC management must strive to uphold the integrity/reliability of raw materials (here: fabrics, cotton, leathers), producing processes, facilities, and data to ensure the products are Halal from farm to consumer (Ali, Zhan, Alam, Tse, \& Tan, 2017). Islamic clothing companies must ensure their products are derived from materials/fabrics permitted by Islamic laws that require hygiene, comfort, and safety. For example, (1) the styles must follow the Islamic dress code, e.g., modest, not tight, not transparent, and loose to cover body shape (Hwang \& Kim, 2020), and (2) the garments must contain high-quality materials to safeguard consumers from skin problems, e.g., skin cancer (Dumas, 2016). Every risk affecting ICSC can damage brand image and consumers' well-being. Thus, it can be assumed that the ICSC deals with more risks than a conventional clothing supply chain. While conventional clothing companies face significant issues such as demand volatility and the fast-changing trend in clothing, the Islamic clothing industry faces more significant problems maintaining its design's modesty under both circumstances (i.e., sensitive consumers and swift fashion movement). More than that, ICSC deals with numerous problems such as inconsistency of Halal principles in clothing, inaccessibility of devoted facilities, Halal 
fabrics, leathers, and other raw materials make the ICSC more vulnerable than the traditional supply chain. Thus, assessing risks becomes an entire segment of ICSC management to control those issues. Practical analysis of those risks can help companies expand strategies to incorporate and control Halal activities in their ICSC.

However, to the best of the authors' knowledge, no previous studies provide a systematic model for risk assessment and mitigation in the ICSC. Only two significant works focus on assessing and mitigating risks in the Islamic clothing companies, i.e., studies conducted in Indonesia (Dewi, Syairudin, \& Nikmah, 2015) and Yogyakarta (Isfianadewi, Pambudi, Siswanti, Surjanti, \& Muafi, 2018). However, none of them mentions the Halal practices in the supply chain, which is critical in today's business development for at least three reasons. Firstly, Halal certification organizations dedicated to the Islamic fashion sector are emerging (Textile \& Clothing, 2020), signifying that these bodies will require companies to apply Halal principles in their ICSCs to get Halal certificates for their products. Secondly, the government of Muslim majority countries such as Indonesia has started to oblige every Islamic product, including clothing and textile, to implement a Halal logo (Berita Bisnis, 2019), signifying the big customers' demands Halal-certified goods, including clothing products. Thirdly, enterprises are organizing to be observantly evaluated for Halal practices in their ICSCs (Seth, 2016) either by those Halal certification bodies, government regulations, or by companies' self-commitment to implement Halal integrity businesses. Consequently, evaluating risks in managing Halal practices in the ICSC is vital for the companies to manage the risks effectively for their sustainable business operations, answering the mentioned three challenges.

Based on those arguments, this study sets the following objectives: (1) discover the risks in the management and implementation of Halal principles in the Islamic clothing supply chain (ICSC); (2) quantitatively inspect the risks employing the Best-Worst approach; and (3) propose several practical implications for managing Halal system in the ICSC.

The remaining of this study is presented in the following order: (i) Part 2 is a literature review on the Halal supply chain and ICSC, (ii) Part 3 describes the Best Worst approach in research methodology, (iii) Part 4 demonstrates the data collection, (iv) Part 5 illustrates the findings of the study, (v) Part 6 provides the results' discussion, (vi) Part 7 presents the conclusion and practical implications, and (vi) Part 8 suggests the limitations of the study and future research guidance.

\section{LITERATURE REVIEW}

As indicated in the introduction section, ICSC risk management does not obtain enough attention in contemporary literature, and it is still few. ICSC has similar risks to conventional clothing supply chains, involving the risks in planning, producing stage, and demand; however, ICSC faces numerous extra risks linked to Halal integrity. Halal supply chain management's primary emphasis is Halal integrity, typically because of raw materials and international outsourcing with many supply partners globally. Particularly, Halal integrity associated-risks imply the unpredicted events that can disturb the commodity's Halal level, from the starting point until the finishing point of the supply chain (Khan et al., 2021). Halal integrity-associated risks grow in distinct stages of the supply chain, i.e., the resourcing stage, 
the producing stage, and the distribution stage (Tieman, 2017). The mentioned risks might initiate haram (unlawful/non- Halal) manufacturing, unhygienic, contaminated, and lowvalue clothing products that can destroy the brand image and disrupt the business process's efficacy.

According to Halal principles in clothing announced by the Halalworld Institute (Sumarliah et al., 2021), Islamic clothing goods need to fulfill some requirements to be produced and consumed, e.g.: (1) for Muslim consumers, both men and women must have modesty in design/styles; specifically for women is not tight, not transparent, not showing body shape, and concealing whole bodies excluding facial and palm, and for men is not using gold, golden accessories, and authentic silk, (2) for leather/fabrics must avoid using haram/unlawful the parts of pig or animals that are not butchered by Islamic way, (3) clothing products must have proper cleansing, not containing unclean harmful materials, and not touched/contaminated by haram products. The global Islamic clothing industry's growth has forced corporate managers to evaluate their ICSCs and find ways to better abide by Halal ethics above their company operation (Seth, 2016). The Halal certification unions committed to the Halal/Islamic clothing sector are emerging (Textile \& Clothing, 2020); thus, enterprises are developing to be considerately appraised for Halal values implementation in their ICSCs (Seth, 2016). Consequently, managers must understand the risks that can disturb the Halal principles' adoption in their business operations and enhance risk management to alleviate those risks.

Numerous studies emphasize risk management in the Halal supply chain; however, those focusing on Islamic/Halal clothing products are scarce. There are only two prominent studies specific to Islamic clothing to the best of the authors' knowledge. First, Isfianadewi et al. (2018) identify 11 significant risks in the new product development of Islamic fashion products and proposed mitigation strategies for those risks. Second, Dewi et al. (2015) discovered four key risks (i.e., management, production, marketing, and finance risk) and 22 significant sub-risks in the ICSC management and proposed mitigation strategies for those risks. The research also includes contemporary studies focusing on other Islamic goods' supply chain management to discover ICSC risks, such as the Islamic food supply chain. The reason is that the Halal/Islamic standards must be implemented to every commodity that Muslims consume, not only foods but also include clothes; therefore, the features of the other Islamic product supply chain's Halal integrity is in line with that of Islamic clothing supply chain (Sumarliah et al., 2021). As an illustration, the Islamic food supply chain strictly forbids using haram ingredients like pig elements in the resourcing point; so does ICSC forbid using pig elements, such as leather shoes, bags, and jackets (Sumarliah et al., 2021). Some notable research works emphasizing other Islamic goods supply chains are as follows. First, (Ali, Tan, Pawar, \& Makhbul, 2014) confirm Halal-integrity risks in the Islamic product supply chain and categorize them into six groups: raw-material risk, outsourcing risk, manufacturing risk, logistics risk, service risk, and product-safety risk, where supply chain integration is the effective risk management. Second, (Tan, Ali, Makhbul, \& Ismail, 2017) examine the effect of external integration on Halal values and recommend that an externalintegration approach is vital in adopting a Halal guarantee scheme. Next, Tieman (2011) finds that the market and product features are significant factors influencing the Halal supply chain. Further, Tieman (2017) suggests comprehensive risk management in the Halal supply 
chain by mitigating Halal-integrity risks, i.e., resourcing risk, logistic risk, corporate operation risk, and supply chain system risk. Finally, other scholars discover and evaluate 19 risks linked to Islamic/Halal food security employing the Bayesian-network method (Wahyuni, Vanany, Ciptomulyono, \& Purnomo, 2020).

\section{METHOD}

The paper employs a two-step methodology to evaluate the ICSC management risks, as presented in Figure 1. The first step includes identifying the risks via an in-depth literature review and confirmed those risks with the survey questionnaire sent to specialists. The completed information is achieved from the specialists, and 34 risks are verified, classified into seven groups (key risks).

The second step is using the Best-Worst approach to prioritize the verified risks. Based on Rezaei (2015), Best-Worst is a well-organized and operative multi-criteria decisionmaking technique. Only recommendation comparison is completed in the Best-Worst technique, implying every decisive factor (here: risk) competes only contrary to the best and worst factor over linear scales. The technique is easy to adopt and time-efficient because of the only reference comparison (Rezaei, 2015). Therefore, this technique avoids consuming much time of the authors and specialists because it needs not many pairwise comparisons.

When comparing the best decisive factor, the authors verify the best factor's preference over the other factor represented by $\ddot{A}_{B}=\left(\ddot{a}_{B 1}, \ddot{a}_{B 2}, \ldots, \ddot{a}_{B n}\right)$ vector. Comparably, when comparing the decisive factor (risk) with the worst decisive factor, the other decisive factors' preference over the worst factor is verified and denoted by the vector $\ddot{A}_{W}=\left(\ddot{a}_{1 W}, \ddot{a}_{2 W}, \ldots, \ddot{a}_{n W}\right)$. Those pairwise comparisons are completed using 1-9 linear scales. Furthermore, the Best-Worst technique offers several benefits which are not found in other multi-criteria decision-making techniques, e.g., a technique for order of preference by similarity to ideal solution (TOPSIS), analytic network process (ANP), and analytic hierarchy process (AHP) (Khan et al., 2018; Prakash \& Barua, 2016). Compared to AHP, the BestWorst technique requires fewer data and delivers a more reliable outcome. Because of the mentioned benefits, this technique's adoption is recognized in some contemporary research works (e.g., Bari Ahmadi, Kusi-Sarpong, \& Rezaei, 2017; Gupta \& Barua, 2017; Pamučar, Petrović, \& Ćirović, 2018; Rezaei, Kothadiya, Tavasszy, \& Kroesen, 2018; Vishnupriyan \& Manoharan, 2018). The two steps of the methodology are presented in Figure 1 and described in the next part of this paper. 
Figure 1: Research Methodology

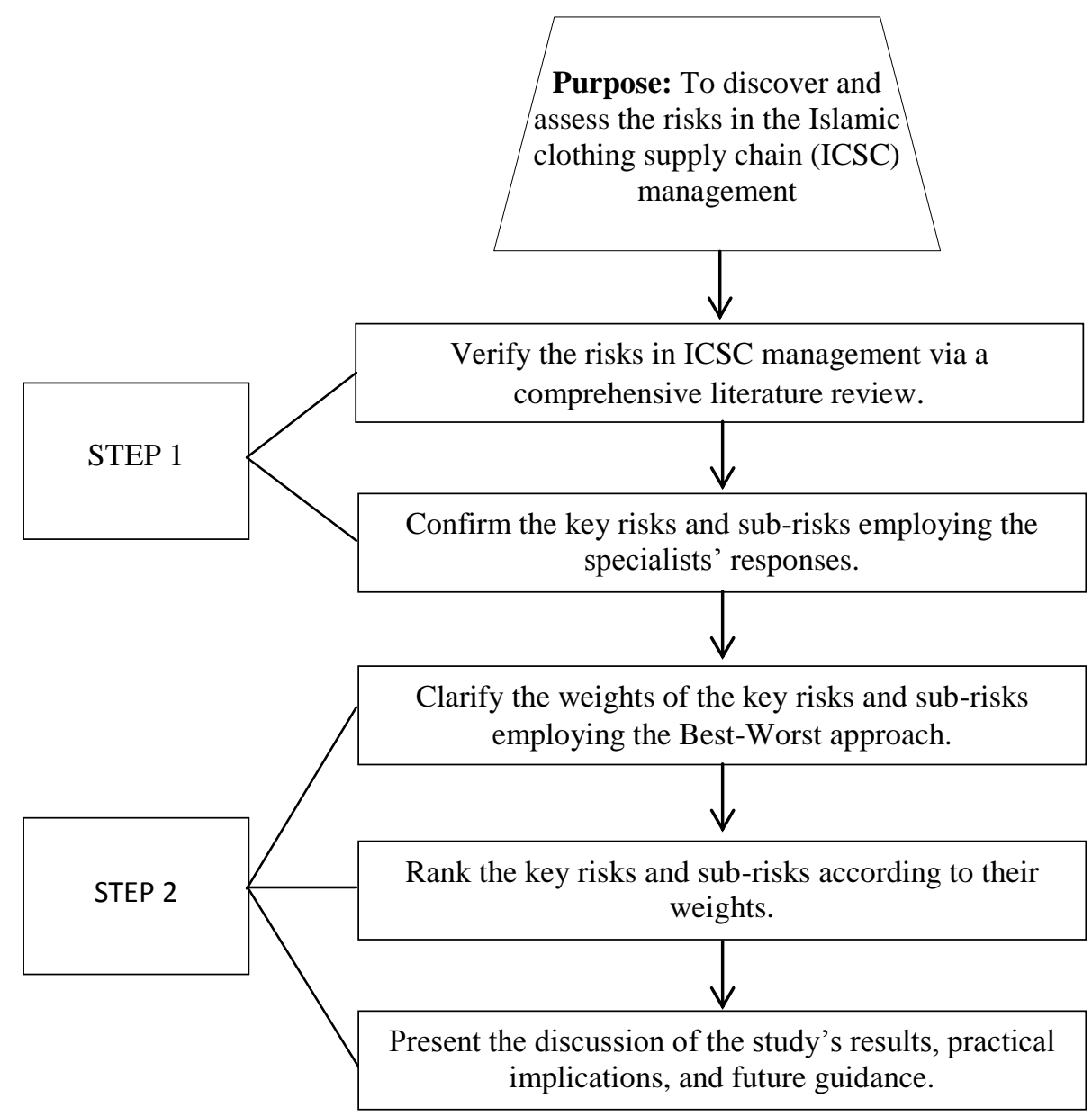

\section{Identifying the risks in the ICSC management}

The study's comprehensive literature review and specialists' responses identify thirtyfour risks related to ICSC management. The Specialists' responses are achieved via an online questionnaire. The target specialists are experienced at least five years in the Halal industry, especially in the Islamic clothing business, and located in OIC (Organization of Islamic Cooperation) countries such as Indonesia, Pakistan, Turkey, Malaysia, and others. The detailed data collection method and the specialists' profiles are presented in section 4, "Data Collection."

At first, the authors discover 40 risks via a comprehensive literature review, and later, those risks are presented in the survey questionnaire to the specialists who give feedback on the risks' significance. After the completed data is gathered, ten risks are eliminated, and three new risks are included. Thus, thirty-four risks are confirmed and classified into seven critical risks according to the specialists' reference.

\section{Clarify the risks' weights through the Best-Worst approach}

The weights of decisive factors (risks) are examined using a currently extended multicriteria decision-making (MCDM) approach, i.e., the Best-Worst technique. Based on Rezaei (2015), this technique includes five stages to originate the risks' weights as follows: 
The first stage identifies the decisive factors (i.e., key risks and sub-risks) using both literature review and specialists' responses/opinions. The second stage determines the best (most significant) factor and the worst (least important) factor. Identifying the best and worst factors among the all discovered factors is completed by the specialists as decision-makers. $F_{\text {.B. }}$ signifies the best factor, and F.w. represents the worst factor.

The third stage is executing the recommendation comparisons for the most significant decisive factor. The best factor's preference is decided over all the other factors employing 1 to 9 measurement scale with the Specialist response and signified by the following vector:

$$
\ddot{A}_{B}=\left(\ddot{a}_{B 1}, \ddot{a}_{B 2}, \ldots, \ddot{a}_{B n}\right)
$$

Where $\ddot{A}_{B}$ refers to the Best-to-Others vectors, $\ddot{a}_{B j}$ denotes the favored best decisive factor $\left(\mathrm{F}_{. B .}\right)$ over factor $j(\mathrm{Fj})$ and $\ddot{a}_{B B}=1$. In this study, the decisive factors are vital risks and sub-risks.

The fourth stage is executing the recommendation comparisons for the worst factor. The favored other factors are decided over the worst factor employing 1 to 9 measurement scale with the Specialist response and signified by the following vector:

$$
\ddot{A}_{W}=\left(\ddot{a}_{1 W}, \ddot{a}_{2 W}, \ldots, \ddot{a}_{n W}\right)^{T}
$$

Where $\ddot{A}_{W}$ implies the Others-to-Worst vectors, $\ddot{a}_{j W}$ denotes the favored factor $\mathrm{j}(\mathrm{Fj})$ over the worst factor $\left(\mathrm{F}_{\text {.W. }}\right)$ and $\ddot{a}_{W W}=1$.

The fifth stage is determining the factors' optimum weights $\left(\ddot{W}_{1}^{*}, \ddot{W}_{2}^{*}, \ldots . . \ddot{W}_{n}^{*}\right)$ that should meet these conditions: every twosome of $\ddot{W}_{B} / \ddot{W}_{j}$ and $\ddot{W}_{j} / \ddot{W}_{W}$ require $\ddot{W}_{B} / \ddot{W}_{j}=\ddot{a}_{B j}$ and $\ddot{W}_{j} / \ddot{W}_{W}=\ddot{a}_{j W}$. Thus, to fulfill these requirements, the researchers must diminish the highest among the series of $\left\{\left|\ddot{W}_{B}-\ddot{a}_{B j} \ddot{W}_{j}\right|,\left|\ddot{W}_{j}-\ddot{a}_{j W} \ddot{W}_{W}\right|\right\}$ and the model becomes:

$$
\begin{gathered}
\min \max \left\{\left|\ddot{W}_{B}-\ddot{a}_{B j} \ddot{W}_{j}\right|,\left|\ddot{W}_{j}-\ddot{a}_{j W} \ddot{W}_{W}\right|\right\} . \\
\text { Conditional on: } \\
\sum_{j} \ddot{W}_{j}=1 \\
\ddot{W}_{j} \geq 0 ; \text { for all } j
\end{gathered}
$$

Model (1) is converted into the linear model as follows :

$$
\operatorname{Min} \ddot{\varepsilon}^{L} \text { s.t. }\left\{\begin{array}{c}
\left|\frac{\ddot{W}_{B}}{\mid \ddot{W}_{j}}-\ddot{a}_{B j}\right| \leq \ddot{\varepsilon}^{L} \text { for all } j \\
\left|\frac{\ddot{W}_{W}}{\ddot{W}_{W}}-\ddot{a}_{B j W}\right| \leq \ddot{\varepsilon}^{L} \text { for all } j \\
\sum_{j} \ddot{W}_{j}=1 \\
\ddot{W}_{j} \geq 0 \text { for all } j
\end{array}\right.
$$

Each factor's optimum weight $\left(\ddot{W}_{1}^{*}, \ddot{W}_{2}^{*}, \ldots . . \ddot{W}_{n}^{*}\right)$ and $\ddot{\varepsilon}^{L}$ 's optimum value is achieved by resolving the model (2). Next, the comparisons' consistency level is checked. The comparisons' consistency level relies on the $\ddot{\varepsilon}^{L}$ value; the nearer the value to 0 (zero) implies 
the greater consistency. Rezaei (2016) recommends that the $\ddot{\varepsilon}^{L}$ the value should be nearer to 0 for the right consistency.

\section{Data Collection}

Based on the in-depth literature review, the authors formulated a survey questionnaire to verify the significance of the risks in the ICSC activities. A 1 to 9 measurement scale is used in the survey to decide the significance weights of the risks. For example, below is the questionnaire form and how it can be responded to - this is according to the second stage until the fourth stage of the Best-Worst method mentioned above (in the research methodology section). In this sample, specialists are required to assess the significance of the critical risks in ICSC. Firstly, the specialists should point out the most and the least significant risks (the second stage), e.g., Retailing is selected as the most significant risk and Viability as the least significant risk.

1. Some 'key risks' can influence the supply chain in the Islamic clothing industry, as the following list. From your perspective, what is the BEST (most significant) and the WORST (the least significant risks)?

\begin{tabular}{|c|c|c|c|}
\hline Key risks & Definition & The best & The worst \\
\hline Resourcing & $\begin{array}{l}\text { Risk related to resourcing stage of the supply chain } \\
\text { (e.g., procurement/sourcing of Halal materials/fabrics } \\
\text { for Islamic clothing goods) }\end{array}$ & $X$ & \\
\hline Producing & $\begin{array}{l}\text { Risk related to the production stage of the supply } \\
\text { chain (e.g., manufacture and design concept of } \\
\text { Islamic clothing products) }\end{array}$ & & \\
\hline Retailing & $\begin{array}{l}\text { Risk related to the retailing stage of the supply chain } \\
\text { (e.g., selling and marketing of Islamic clothing } \\
\text { products) }\end{array}$ & & \\
\hline Viability & $\begin{array}{l}\text { Risk related to sustainability of Islamic clothing } \\
\text { industry }\end{array}$ & & $\mathrm{X}$ \\
\hline Management & $\begin{array}{l}\text { Risk related to management inside the companies } \\
\text { focusing on the Islamic clothing business }\end{array}$ & & \\
\hline Regulation & $\begin{array}{l}\text { Risk related to government regulation and Halal } \\
\text { certification bodies that can affect the operations of } \\
\text { the Islamic clothing industry }\end{array}$ & & \\
\hline Technological & $\begin{array}{l}\text { Risk related to technology and information sharing } \\
\text { implemented in the company }\end{array}$ & & \\
\hline
\end{tabular}

After the best key risk has been decided, specialists should point out their preferences concerning the significance of that risk over the other key risks (the third stage).

2. You have chosen $X X$ (in this illustration, retailing) as the best/most significant critical risk. Please decide your preferred ratio of this crucial risk over the other key risks with a nine-point scale of 1-9 (1 means equally significant and nine implies the Retailing is more significant than other risks) 


\begin{tabular}{|l|l|l|l|l|l|l|l|}
\hline \multirow{2}{*}{$\begin{array}{c}\text { Best-to- } \\
\text { Others }\end{array}$} & \multicolumn{9}{|c|}{ Key/critical risks } \\
\cline { 2 - 8 } & Resourcing & Producing & Retailing & Viability & Management & Regulation & Technology \\
\hline $\begin{array}{l}\text { Best key } \\
\text { risk: } \\
\text { Retailing }\end{array}$ & 5 & 2 & 1 & 6 & 3 & 3 & 8 \\
\hline
\end{tabular}

After that, the specialists should point out the significance of other risks over the worst (least significant) risk (the fourth stage).

3. You have chosen XX (in this illustration, viability risk) as the worst/least significant critical risk. Please decide your preferred ratio of this crucial risk over the other key risks with a nine-point scale of 1-9 (1 means equally significant and 9 implies the resourcing-stage risk is more significant than other risks)

\begin{tabular}{|l|c|}
\hline Others-to-Worst & Worst critical risk: Viability \\
\hline Resourcing & 3 \\
\hline Producing & 7 \\
\hline Retailing & 9 \\
\hline Viability & 1 \\
\hline Management & 6 \\
\hline Regulation & 6 \\
\hline Technology & 2 \\
\hline
\end{tabular}

Likewise, specialists are asked to assess the sub-risks' significance to calculate the seven key risks analyzed in the research, as demonstrated by the sample. Most data for the research were collected using an electronic questionnaire among specialists, intellectuals, and corporate leaders/practitioners in the Halal supply chain and Islamic clothing industry. The study identified the focus participants from leading Islamic fashion companies and the best Islamic colleges in the OIC countries. The leading Islamic clothing firms are obtained via Branded Girls and Allure, which inform the best worldwide hijab brands, while the best Islamic colleges are obtained via Q.S. World University Rankings, a website that informs colleges' rankings according to study fields. ResearchGate is also employed to discover specialists.

From the sources mentioned above, the author found the total population of 145 potential specialists, which consists of those from 28 major Islamic fashion firms ("Top 18" (n.d.); Moazzam, 2020), 30 best-ranking Islamic universities in OIC countries (University Rankings, 2020), and 87 'Halal supply chain' research articles published in peer-reviewed journals indexed by Scopus since 2010 until 2020 (with journal rankings ranged from Q1 to Q4). This research applied the sample based on the advised table of sample size (Krejcie \& Morgan, 1970), signifying that of a total population of 145, this study's sample size should be 105 specialists. Thus, the author concentrated on collecting information from those 105 specialists. The specialists were selected for their broad understandings of the Halal S.C. and ICSC risk problems. It is expected that the specialists can reflect numerous elements inside the business's working situation in their risk assessment. From all questionnaires spread to 
105 specialists during two months, 71 were returned to the author, and only 56 with completed answers and thus usable for further examination, implying a response rate of $53.3 \%$. Table 1 presents the specialists' profile.

Table 1: Specialists' Profile

\begin{tabular}{|c|c|c|}
\hline Descriptions & Number of specialist (s) & Percentage \\
\hline Field of expertise* & & \\
\hline Halal supply chain management & 19 & $34 \%$ \\
\hline Islamic fashion (hijab) business & 16 & $29 \%$ \\
\hline Halal certification & 7 & $13 \%$ \\
\hline Halal logistics & 6 & $11 \%$ \\
\hline Islamic marketing & 5 & $9 \%$ \\
\hline Islamic finance & 3 & $5 \%$ \\
\hline Location of specialists & & \\
\hline Indonesia & 21 & $38 \%$ \\
\hline Pakistan & 13 & $23 \%$ \\
\hline Malaysia & 11 & $20 \%$ \\
\hline UAE & 5 & $9 \%$ \\
\hline Kazakhstan & 3 & $5 \%$ \\
\hline The Gambia & 2 & $4 \%$ \\
\hline Mali & 1 & $2 \%$ \\
\hline Total & 56 & $100 \%$ \\
\hline
\end{tabular}

Note: *Some specialists provide multiple expertise fields

Table 1 displays that the specialists' representation of expertise fields is satisfactory, from Halal S.C. management to Islamic finance. All specialists located in OIC countries are from Indonesia (38\%), the biggest Muslim-populated country globally.

\section{FINDING}

The research identifies the risks in Islamic clothing supply chain (ICSC) management by combining the specialists' standpoints and a comprehensive literature review. Next, the Best-Worst method is applied to prioritize ICSC management's risks. Based on the completed survey questionnaire with 56 specialists and an in-depth literature review, 34 subrisks related to the ICSC are confirmed and classified into seven groups. Table 2 presents these ICSC's critical risks and sub-risks and the sources from literature and specialist's input. It is evident from the table that the 34 sub-risks discovered in this study are classified into seven key/critical risks, i.e.: (1) Resourcing risk, which consists of six sub-risks (coded as RES1-RES6), (2) Producing risk, which comprises five sub-risks (indicated by PRO1-PRO5), (3) Retailing risk, which includes four sub-risks (denoted as RET1-RET4), (4) Viability risk, which contains five sub-risks (typified by VIA1-VIA5), (5) Management risk, which entails five sub-risks (correspond to MAN1-MAN5), (6) Regulation risk, which involves four sub-risks (represented as REG1-REG4), and (7) Technological risk which is made of five sub-risks (symbolized as TEC1-TEC5). 
Table 2: Risks and Sub-Risks in the ICSC Management

\begin{tabular}{|c|c|c|c|}
\hline Key/Critical Risks & CODE & Sub-risks & Sources \\
\hline \multirow[t]{6}{*}{$\begin{array}{l}\text { Resourcing } \\
\text { risk (RES) }\end{array}$} & RES1 & $\begin{array}{l}\text { Poor-quality supply partners: } \\
\text { postponements, order completion not in } \\
\text { compliance, and slow delivery time }\end{array}$ & $\begin{array}{l}\text { Dewi et al. (2015); } \\
\text { Isfianadewi et al. (2018) }\end{array}$ \\
\hline & RES2 & $\begin{array}{l}\text { Inadequate information on raw materials due } \\
\text { to the unreliable sources of fabrics or not } \\
\text { given by the supplier }\end{array}$ & $\begin{array}{l}\text { Ali et al. (2017); Soon et } \\
\text { al. (2017) }\end{array}$ \\
\hline & RES3 & $\begin{array}{l}\text { The insolvencies of primary supply partners, } \\
\text { disrupting the firm's operation }\end{array}$ & $\begin{array}{l}\text { Khan et al. (2020), Ali et } \\
\text { al. (2016) }\end{array}$ \\
\hline & RES4 & $\begin{array}{l}\text { Inaccessibility of Halal fabrics causing the use } \\
\text { of unlawful materials to make clothing }\end{array}$ & $\begin{array}{c}\text { Isfianadewi et al. (2018); } \\
\text { Tieman } \\
(2011)\end{array}$ \\
\hline & RES5 & $\begin{array}{l}\text { The dearth of supply partners providing Halal } \\
\text { resources, including materials for Islamic } \\
\text { clothing production }\end{array}$ & $\begin{array}{l}\text { Ali \& Suleiman (2018); } \\
\text { Haleem and Khan (2017) }\end{array}$ \\
\hline & RES6 & $\begin{array}{l}\text { Low quality, unclean, impure, and unhygienic } \\
\text { raw materials (here: leathers, cotton, fabrics) }\end{array}$ & $\begin{array}{l}\text { Ali \& Suleiman, (2018); } \\
\text { Khan et al. (2018); van } \\
\text { der Spiegel et al. (2012) }\end{array}$ \\
\hline \multirow[t]{5}{*}{ Producing risk (PRO) } & PRO1 & $\begin{array}{l}\text { Improper packing, e.g., the risk of using non- } \\
\text { Halal packing materials in the packing process } \\
\text { of Islamic clothing products }\end{array}$ & Tieman (2011) \\
\hline & $\mathrm{PRO} 2$ & $\begin{array}{l}\text { Inadequate machines, equipment, and } \\
\text { facilities for producing Islamic clothing } \\
\text { products }\end{array}$ & Dewi et al. (2015); \\
\hline & PRO3 & $\begin{array}{l}\text { Joint services (here: scissors, cutting } \\
\text { machines, sewing machines, and storage) that } \\
\text { cause the cross-pollution between Halal and } \\
\text { haram clothing products }\end{array}$ & $\begin{array}{l}\text { Sumarliah et al. (2021); } \\
\text { Tieman et al. (2012) }\end{array}$ \\
\hline & PRO4 & $\begin{array}{l}\text { The less- advanced design models/ideas for } \\
\text { Islamic clothing products }\end{array}$ & $\begin{array}{l}\text { Dewi et al. (2015); } \\
\text { Isfianadewi et al. (2018) }\end{array}$ \\
\hline & PRO5 & $\begin{array}{l}\text { Errors in clothing manufacture, e.g., pattern- } \\
\text { cutting faults causing higher costs }\end{array}$ & Isfianadewi et al. (2018) \\
\hline \multirow[t]{4}{*}{ Retailing risk (RET) } & RET1 & The swift-changing growth of clothing trends & \multirow{3}{*}{ Dewi et al. (2015) } \\
\hline & RET2 & $\begin{array}{l}\text { Inadequate qualification/skills of salespersons } \\
\text { in the company }\end{array}$ & \\
\hline & RET3 & $\begin{array}{l}\text { Demand unpredictability of the Islamic } \\
\text { clothing goods }\end{array}$ & \\
\hline & RET4 & $\begin{array}{l}\text { Inappropriate separation for the Halal/Islamic } \\
\text { and not Halal clothing products, e.g., using } \\
\text { shared display racks, can cause cross- } \\
\text { contamination and product-status shift from } \\
\text { Halal to haram }\end{array}$ & $\begin{array}{l}\text { Sumarliah et al. (2021); } \\
\text { Tieman et al. } \\
\text { (2012) }\end{array}$ \\
\hline \multirow[t]{4}{*}{ Viability risk (VIA) } & VIA1 & $\begin{array}{l}\text { Barriers in foreign currency for international } \\
\text { trade }\end{array}$ & \multirow[b]{2}{*}{ Dewi et al. (2015) } \\
\hline & VIA2 & 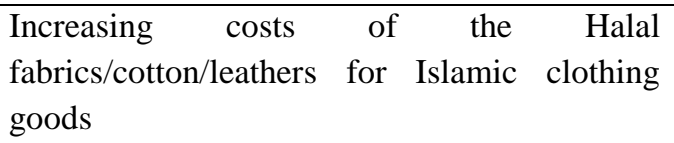 & \\
\hline & VIA3 & $\begin{array}{l}\text { Inappropriate waste disposal/ recycling } \\
\text { practice for leftover products }\end{array}$ & Haleem et al. (2020) \\
\hline & VIA4 & Hijab ban/restriction in purchasing and & Specialist's input \\
\hline
\end{tabular}




\begin{tabular}{|c|c|c|c|}
\hline & & $\begin{array}{l}\text { wearing Islamic clothing goods, often for } \\
\text { political purposes. }\end{array}$ & \\
\hline & VIA5 & Labor-manager disagreement (strike) & \\
\hline Management & MAN1 & Unsuccessful demand estimate & \\
\hline risk (MAN) & MAN2 & $\begin{array}{l}\text { The lack of the company's focus on handling } \\
\text { the growing risks in the ICSC }\end{array}$ & Dewi et al. . (2015); \\
\hline & MAN3 & $\begin{array}{l}\text { Team-coordination barriers inside the Islamic } \\
\text { clothing companies }\end{array}$ & $\begin{array}{l}\text { Dewi et al. . (2015); } \\
\text { Isfianadewi et al. (2018) }\end{array}$ \\
\hline & MAN4 & $\begin{array}{l}\text { Managers' lack of dedication to control the } \\
\text { ICSC }\end{array}$ & $\begin{array}{c}\text { Ngah et al. (2014); Dewi } \\
\text { et al. (2015); } \\
\text { Tan et al. (2017) }\end{array}$ \\
\hline & MAN5 & $\begin{array}{l}\text { Unsuccessful policy and plan of management } \\
\text { to implement the ICSC scheme }\end{array}$ & $\begin{array}{l}\text { Ali et al. } \\
(2017)\end{array}$ \\
\hline $\begin{array}{l}\text { Regulation risk } \\
\text { (REG) }\end{array}$ & REG1 & $\begin{array}{l}\text { Many Halal certification organizations, which } \\
\text { triggers misperceptions among customers } \\
\text { about their legitimacy }\end{array}$ & $\begin{array}{c}\text { Ali \& } \\
\text { Suleiman, (2018); } \\
\text { Haleem et al. (2019) }\end{array}$ \\
\hline & REG2 & $\begin{array}{l}\text { Absence of funding for the campaign of Halal } \\
\text { products, especially Islamic clothing products }\end{array}$ & Khan and Haleem (2016) \\
\hline & REG3 & $\begin{array}{l}\text { The government's restriction by-law on the } \\
\text { Halal industry, including the Islamic clothing } \\
\text { industry }\end{array}$ & $\begin{array}{c}\text { Ab Talib et al. } \\
(2015) ; \text { Alzeer et al. } \\
(2018)\end{array}$ \\
\hline & REG4 & $\begin{array}{l}\text { False Halal logo of the goods issued by } \\
\text { manufacturers or non-reliable Halal } \\
\text { certification bodies }\end{array}$ & $\begin{array}{c}\text { Ali \& } \\
\text { Suleiman (2018); Rusni } \\
\text { et al. (2016) }\end{array}$ \\
\hline $\begin{array}{l}\text { Technological } \\
\text { risk (TEC) }\end{array}$ & TEC1 & $\begin{array}{l}\text { Difficulty in the analysis of the Halal status of } \\
\text { Islamic clothing goods }\end{array}$ & Ali and Suleiman (2018) \\
\hline & TEC2 & $\begin{array}{l}\text { Deficiency in data integrity, i.e., the lack of } \\
\text { actions to deliver trustworthy information of } \\
\text { products to consumers }\end{array}$ & Ali et al. (2017) \\
\hline & TEC3 & Unsatisfactory information sharing & Haleem et al. (2019) \\
\hline & TEC4 & $\begin{array}{l}\text { Information-flow ineffectiveness among ICSC } \\
\text { partners }\end{array}$ & $\begin{array}{c}\text { Zailani } \\
\text { et al. }(2010)\end{array}$ \\
\hline & TEC5 & High budget/expenses for technology adoption & Khan et al. (2018) \\
\hline
\end{tabular}

The list of critical risks in the ICSC is confirmed; thus, the authors request the specialists to provide their replies to pairwise comparison rankings for every main risk and sub-risks. The most and least significant risks for the key risks and sub-risks are verified (Tables 3-10). The best risk verified using the Best-Worst method is the most significant risk and should be addressed first, while the worst risk is the least significant factor and thus least significant and can be tackled later after all other risks. After that, the linear scale (1-9) is applied to rank the critical risk and sub-risks' pairwise comparison. Tables 3-10 present the findings for critical risks and sub-risks' pairwise comparison as follows:

Table 3 displays the findings of the critical risk's comparison by the specialist's recommendation. It is evident from the table that among seven critical risks in the ICSC (i.e., RES, PRO, RET, VIA, MAN, REG, and TEC), specialists selected Retailing risk (RET) as the best key risk and Viability risk (VIA) as the worst key risk. Specialists measured Best-toOthers, the pairwise comparisons between the best key risk (i.e., RET) over other vital risks, 
using scales of 1-9 (1 means equally significant and nine implies RET is more significant than the other risk). The scales are displayed in the second row of the table. A similar way is applied to the worst key risk (i.e., VIA) over other vital risks, namely Others-to-Worst. The pairwise comparison scales are presented in the right side column of the table where specialists gauged a scale of 1-9 (1 means equally essential, and nine means another critical risk is more critical than VIA or VIA is less important than the other critical risk in the ICSC).

Table 3: Key Risks' Comparisons

\begin{tabular}{|l|c|c|c|c|c|c|c|}
\hline Best-to-Others & RES & PRO & RET & VIA & MAN & REG & TEC \\
\hline Best key risk: RET & 5 & 2 & 1 & 6 & 3 & 3 & 8 \\
\hline \multicolumn{7}{|l|}{} \\
\hline Others-to-Worst & & & & & & Worst critical risk: VIA \\
\hline RES & & & & & & 3 \\
\hline PRO & & & & & & 9 \\
\hline RET & & & & & & 6 \\
\hline VIA & & & & & & 6 \\
\hline MAN & & & & & & 2 \\
\hline REG & & & & & & \\
\hline TEC
\end{tabular}

Table 4 presents the pairwise comparison for sub-risks associated with the supply chain's resourcing stage. It is clear from the table that among the six sub-risks in the resourcing stage (i.e., RES1-RES6), the specialists determined RES6 as the best sub-risk and RES3 as the worst sub-risk. The pairwise comparisons between the best sub-risk (RES6) over the other sub-risks are presented in the table's second row, while the worst sub-risk (RES3) over the other sub-risks are displayed in the right-side column of the table. Specialists gauged the Best-To-Others pairwise comparisons employing scales of 1-9 (1 means equally significant, and nine implies that RES6 is more significant than the other sub-risk). Also, measured the Others-to-Worst pairwise comparisons using scales of 1-9 (1 means equally essential, and nine means another sub-risk is more critical than RES3 or RES3 is less important than the other sub-risk in ICSC's resourcing stage).

Table 4: Pairwise Comparisons of Resourcing Risk (RES)

\begin{tabular}{|l|c|c|c|c|c|c|}
\hline Best-to-Others & RES1 & RES2 & RES3 & RES4 & RES5 & RES6 \\
\hline Best sub-risk: RES6 & 5 & 8 & 9 & 2 & 3 & 1 \\
\hline \multicolumn{7}{|l|}{} \\
\hline Others-to-Worst & & & & & Worst sub-risk: RES3 \\
\hline RES1 & & & & & 2 \\
\hline RES2 & & & & & 2 \\
\hline RES3 & & & & & 7 \\
\hline RES4 & & & & & 4 \\
\hline RES5 & & & & & 9 \\
\hline RES6 & & & & & \\
\hline
\end{tabular}

Table 5 displays the pairwise comparison for sub-risks associated with the supply chain's producing stage. It is evident from the table that among the five sub-risks in producing stage (i.e., PRO1-PRO5), specialists chose PRO3 as the best sub-risk and PRO1 as 
the worst sub-risk. The pairwise comparisons between the best sub-risk (PRO3) over the other sub-risks are presented in the table's second row, while the worst sub-risk (PRO1) over the other sub-risks are displayed in the right-side column of the table. Specialists gauged the Best-To-Others pairwise comparisons employing scales of 1-9 (1 means equally significant, and nine implies that PRO3 is more significant than the other sub-risk). Also, measured the Others-to-Worst pairwise comparisons using scales of 1-9 (1 means equally essential, and nine denotes another sub-risk is more critical than PRO1 or PRO1 is less significant than other sub-risk in the ICSC's producing stage).

Table 5: Pairwise Comparisons of Producing Risks (PRO)

\begin{tabular}{|c|c|c|c|c|c|}
\hline Best-to-Others & PRO1 & PRO2 & PRO3 & PRO4 & PRO 5 \\
\hline Best sub-risk: PRO3 & 4 & 3 & 1 & 2 & 5 \\
\hline Others-to-Worst & & & & \multicolumn{2}{|c|}{ Worst sub-risk: PRO1 } \\
\hline PRO1 & & & & \multicolumn{2}{|c|}{2} \\
\hline PRO2 & & & & \multicolumn{2}{|c|}{3} \\
\hline PRO3 & & & & \multicolumn{2}{|c|}{5} \\
\hline PRO4 & & & & \multicolumn{2}{|c|}{4} \\
\hline PRO5 & & & & \multicolumn{2}{|c|}{1} \\
\hline
\end{tabular}

Table 6 exhibits the pairwise comparison for sub-risks associated with the supply chain's retailing stage. It is evident from the table that among the four sub-risks in retailing stage (i.e., RET1-RET4), specialists decided RET4 as the best sub-risk and RET2 as the worst sub-risk. The pairwise comparisons between the best sub-risk (RET4) over the other sub-risks are presented in the table's second row, while the worst sub-risk (RET2) over the other sub-risks are displayed in the right-side column of the table. Specialists gauged the Best-To-Others pairwise comparisons employing scales of 1-9 (1 means equally significant, and nine implies that RET4 is more significant than the other sub-risk). Also, measured the Others-to-Worst pairwise comparisons using scales of 1-9 (1 means equally essential, and nine denotes another sub-risk is more critical than RET2 or RET2 is less critical than other sub-risk in the ICSC's retailing stage).

Table 6: Pairwise Comparisons of Retailing Risks (RET)

\begin{tabular}{|l|c|c|c|c|}
\hline Best-to-Others & RET1 & RET2 & RET3 & RET4 \\
\hline Best sub-risk: RET4 & 3 & 4 & 2 \\
\hline \multicolumn{3}{|l|}{} & & Worst sub-risk: RET2 \\
\hline Others-to-Worst & & & 2 \\
\hline RET1 & & & 3 \\
\hline RET2 & & & 3 \\
\hline RET3 & & & \\
\hline RET4 & & & \\
\hline
\end{tabular}

Table 7 exposes the pairwise comparison for sub-risks associated with viability/sustainability. It is evident from the table that among the five sub-risks in this category (i.e., VIA1-VIA5), specialists decided VIA2 as the best sub-risk and VIA5 as the worst sub-risk. The pairwise comparisons between the best sub-risk (VIA2) over the other sub-risks are presented in the table's second row, while the worst sub-risk (VIA5) over the 
other sub-risks are displayed in the right-side column of the table. Specialists gauged the Best-To-Others pairwise comparisons employing scales of 1-9 (1 means equally significant, and nine implies that VIA2 is more significant than the other sub-risk). Also, measured the Others-to-Worst pairwise comparisons using scales of 1-9 (1 means equally essential, and nine denotes another sub-risk is more critical than VIA5 or VIA5 is less critical than other sub-risk in this group).

Table 7: Pairwise Comparisons of Viability Risks (VIA)

\begin{tabular}{|l|c|c|c|c|c|}
\hline Best-to-Others & VIA1 & VIA2 & VIA3 & VIA4 & VIA5 \\
\hline Best sub-risk: VIA2 & 3 & 1 & 5 & 2 & 9 \\
\hline \multicolumn{5}{|l|}{} \\
\hline Others-to-Worst & & & & Worst sub-risk: VIA5 \\
\hline VIA1 & & & & 6 \\
\hline VIA2 & & & & 3 \\
\hline VIA3 & & & & 7 \\
\hline VIA4 & & & & 1 \\
\hline VIA5 & & & & \\
\hline
\end{tabular}

Table 8 discloses the pairwise comparison for sub-risks associated with management. It is apparent from the table that among the five sub-risks in this category (i.e., MAN1-MAN5), specialists selected MAN5 as the best sub-risk and MAN1 as the worst sub-risk. The pairwise comparisons between the best sub-risk (MAN5) over the other sub-risks are presented in the table's second row, while the worst sub-risk (MAN1) over the other sub-risks are displayed in the right-side column of the table. Specialists gauged the Best-To-Others pairwise comparisons employing scales of 1-9 (1 means equally significant and nine implies that MAN5 is more significant than the other sub-risk). Also, measured the Others-to-Worst pairwise comparisons using scales of 1-9 (1 means equally essential, and nine denotes another sub-risk is more critical than MAN1 or MAN1 is less critical than other sub-risk in the ICSC's management stage).

Table 8: Pairwise Comparisons of Management Risk (MAN)

\begin{tabular}{|l|c|c|c|c|c|}
\hline Best-to-Others & MAN1 & MAN2 & MAN3 & MAN4 & MAN5 \\
\hline Best sub-risk: MAN5 & 8 & 4 & 2 & 3 & 1 \\
\hline \multicolumn{5}{|l|}{} \\
\hline Others-to-Worst & & & & Worst sub-risk: MAN1 \\
\hline MAN1 & & & & 2 \\
\hline MAN2 & & & & 4 \\
\hline MAN3 & & & & 5 \\
\hline MAN4 & & & & 2 \\
\hline MAN5 & & & & 2 \\
\hline
\end{tabular}

Table 9 indicates the pairwise comparison for sub-risks associated with regulation. It is apparent from the table that among the four sub-risks in this category (i.e., REG1-REG4), specialists selected REG3 as the best sub-risk and REG1 as the worst sub-risk. The pairwise comparisons between the best sub-risk (REG3) over the other sub-risks are presented in the table's second row, while the worst sub-risk (REG1) over the other sub-risks are displayed in the right-side column of the table. Specialists gauged the Best-To-Others pairwise 
comparisons employing scales of 1-9 (1 means equally significant and nine implies that REG3 is more significant than the other sub-risk). Also, measured the Others-to-Worst pairwise comparisons using scales of 1-9 (1 means equally essential, and nine denotes another sub-risk is more critical than REG1 or REG1 is less critical than other sub-risk in this category).

Table 9: Pairwise Comparisons of Regulation Risk (REG)

\begin{tabular}{|l|c|c|c|c|}
\hline Best-to-Others & REG3 & REG2 & REG1 & REG4 \\
\hline Best sub-risk: REG3 & 1 & 2 & 5 & 3 \\
\hline \multicolumn{3}{|l|}{} & & \multicolumn{2}{|c|}{ Worst sub-risk: REG1 } \\
\hline Others-to-Worst & & & 4 \\
\hline REG1 & & & 5 \\
\hline REG2 & & & 2 \\
\hline REG3 & & & \\
\hline REG4 & & & \\
\hline
\end{tabular}

Table 10 demonstrates the pairwise comparison for sub-risks associated with technology. It is apparent from the table that among the five sub-risks in this category (i.e., TEC1-TEC5), specialists selected TEC1 as the best sub-risk and TEC2 as the worst sub-risk. The pairwise comparisons between the best sub-risk (TEC1) over the other sub-risks are presented in the table's second row, while the worst sub-risk (TEC2) over the other sub-risks are displayed in the right-side column of the table. Specialists gauged the Best-To-Others pairwise comparisons employing scales of 1-9 (1 means equally significant, and nine implies that TEC1 is more significant than the other sub-risk). Also, measured the Others-to-Worst pairwise comparisons using scales of 1-9 (1 means equally essential, and nine denotes another sub-risk is more critical than TEC2 or TEC2 is less critical than other sub-risk in this category).

Table 10: Pairwise Comparisons of Technological Risk (TEC)

\begin{tabular}{|l|c|c|c|c|c|}
\hline Best-to-Others & TEC1 & TEC5 & TEC3 & TEC4 & TEC2 \\
\hline Best sub-risk: TEC1 & 1 & 5 & 4 & 2 & 8 \\
\hline \multicolumn{5}{|l|}{} \\
\hline Others-to-Worst & & & & Worst sub-risk: TEC2 \\
\hline TEC1 & & & & 8 \\
\hline TEC2 & & & & 3 \\
\hline TEC3 & & & & 5 \\
\hline TEC4 & & & & 5 \\
\hline TEC5 & & & & \\
\hline
\end{tabular}

Tables 3-10 signify the pairwise comparison of every critical risk and sub-risk by the specialists; the next process determines the key risks and sub-risks' weights. Equation (2) is used to calculate the optimum weight of every critical risk, sub-risks, and consistency ratio with Specialists' comparison scores. Table 11 presents the optimum weights of every critical risk and sub-risks. Those weights also display the conversion, in which general weights are multiplied by the critical risk weight with the related sub-risk weight. The consistency ratio of every risk and sub-risks in the research is below 0.1, displaying the findings' high consistency. It is evident from Table 11 that among key/critical risks, retailing risk (RET) has 
the highest weight (0.31499), while viability risk (VIA) has the least weight (0.02827). It implies that RET is the best risk among seven critical risks and VIA is the worst or least important risk in the group based on the specialists' opinion. Table 11 also shows that among a total of thirty-four sub-risks, RET4 is the most significant with a general weight of 0.138965, while PRO5 is the least essential sub-risk with a general weight of 0.001137. The general weight and rank of each sub-risk are displayed in the two rightest-side columns of the table. The detail of local weight and rank of each sub-risk in every group is presented in the 6th and 8th columns of the table.

Table 11: Weights of Critical Risks and Sub-Risks in The ICSC

\begin{tabular}{|c|c|c|c|c|c|c|c|c|c|}
\hline \multicolumn{4}{|c|}{ Key/Critical Risks } & \multicolumn{6}{|c|}{ Sub-risks } \\
\hline Code & Weight & $\begin{array}{c}\text { Consistency } \\
\text { ratio }\end{array}$ & Rank & Code & Weight & $\begin{array}{c}\text { Consistency } \\
\text { ratio }\end{array}$ & $\begin{array}{l}\text { Group } \\
\text { rank }\end{array}$ & $\begin{array}{c}\text { General } \\
\text { weight }\end{array}$ & $\begin{array}{c}\text { General } \\
\text { rank }\end{array}$ \\
\hline \multirow[t]{6}{*}{ RES } & \multirow[t]{6}{*}{0.17365} & \multirow[t]{6}{*}{0.08884} & \multirow[t]{6}{*}{3} & RES1 & 0.09375 & \multirow[t]{6}{*}{0.07261} & 5 & $\begin{array}{c}0.0162 \\
6\end{array}$ & 20 \\
\hline & & & & RES2 & 0.10168 & & 4 & $\begin{array}{c}0.0176 \\
3\end{array}$ & 18 \\
\hline & & & & RES3 & 0.04035 & & 6 & $\begin{array}{c}0.0070 \\
0\end{array}$ & 28 \\
\hline & & & & RES4 & 0.23437 & & 2 & $\begin{array}{c}0.0406 \\
4\end{array}$ & 8 \\
\hline & & & & RES5 & 0.15625 & & 3 & $\begin{array}{c}0.0270 \\
9\end{array}$ & 14 \\
\hline & & & & RES6 & 0.41779 & & 1 & $\begin{array}{c}0.0724 \\
4\end{array}$ & 4 \\
\hline \multirow[t]{5}{*}{ PRO } & \multirow[t]{5}{*}{0.20192} & & \multirow[t]{5}{*}{2} & PRO1 & 0.09105 & \multirow[t]{5}{*}{0.09104} & 4 & $\begin{array}{c}0.0183 \\
6\end{array}$ & 17 \\
\hline & & & & PRO2 & 0.18209 & & 3 & $\begin{array}{c}0.0367 \\
1\end{array}$ & 10 \\
\hline & & & & PRO3 & 0.45523 & & 1 & $\begin{array}{c}0.0917 \\
8 \\
\end{array}$ & 2 \\
\hline & & & & PRO4 & 0.27314 & & 2 & $\begin{array}{c}0.0550 \\
7\end{array}$ & 7 \\
\hline & & & & PRO5 & 0,04032 & & 5 & $\begin{array}{c}0.0011 \\
4\end{array}$ & 34 \\
\hline \multirow[t]{4}{*}{$\overline{\mathrm{RET}}$} & \multirow[t]{4}{*}{0.31499} & & \multirow[t]{4}{*}{1} & RET1 & 0.17674 & \multirow[t]{4}{*}{0.08834} & 3 & $\begin{array}{c}0.0555 \\
9\end{array}$ & 6 \\
\hline & & & & RET2 & 0.11782 & & 4 & $\begin{array}{c}0.0370 \\
6\end{array}$ & 9 \\
\hline & & & & RET3 & 0.26510 & & 2 & $\begin{array}{c}0.0834 \\
8\end{array}$ & 3 \\
\hline & & & & RET4 & 0.44184 & & 1 & $\begin{array}{c}0.1389 \\
7\end{array}$ & 1 \\
\hline \multirow[t]{5}{*}{ VIA } & \multirow[t]{5}{*}{0.02827} & & \multirow[t]{5}{*}{7} & VIA1 & 0.16947 & \multirow[t]{5}{*}{0.07261} & 3 & $\begin{array}{c}0.0047 \\
8\end{array}$ & 29 \\
\hline & & & & VIA2 & 0.43579 & & 1 & $\begin{array}{c}0.0123 \\
0\end{array}$ & 22 \\
\hline & & & & VIA3 & 0.10168 & & 4 & $\begin{array}{c}0.0028 \\
7\end{array}$ & 32 \\
\hline & & & & VIA4 & 0.25421 & & 2 & $\begin{array}{c}0.0071 \\
8\end{array}$ & 27 \\
\hline & & & & VIA5 & 0.04035 & & 5 & $\begin{array}{c}0.0011 \\
4\end{array}$ & 33 \\
\hline MAN & 0.08077 & & 5 & MAN1 & 0.04847 & 0.77596 & 5 & $\begin{array}{c}0.0039 \\
1\end{array}$ & 30 \\
\hline
\end{tabular}




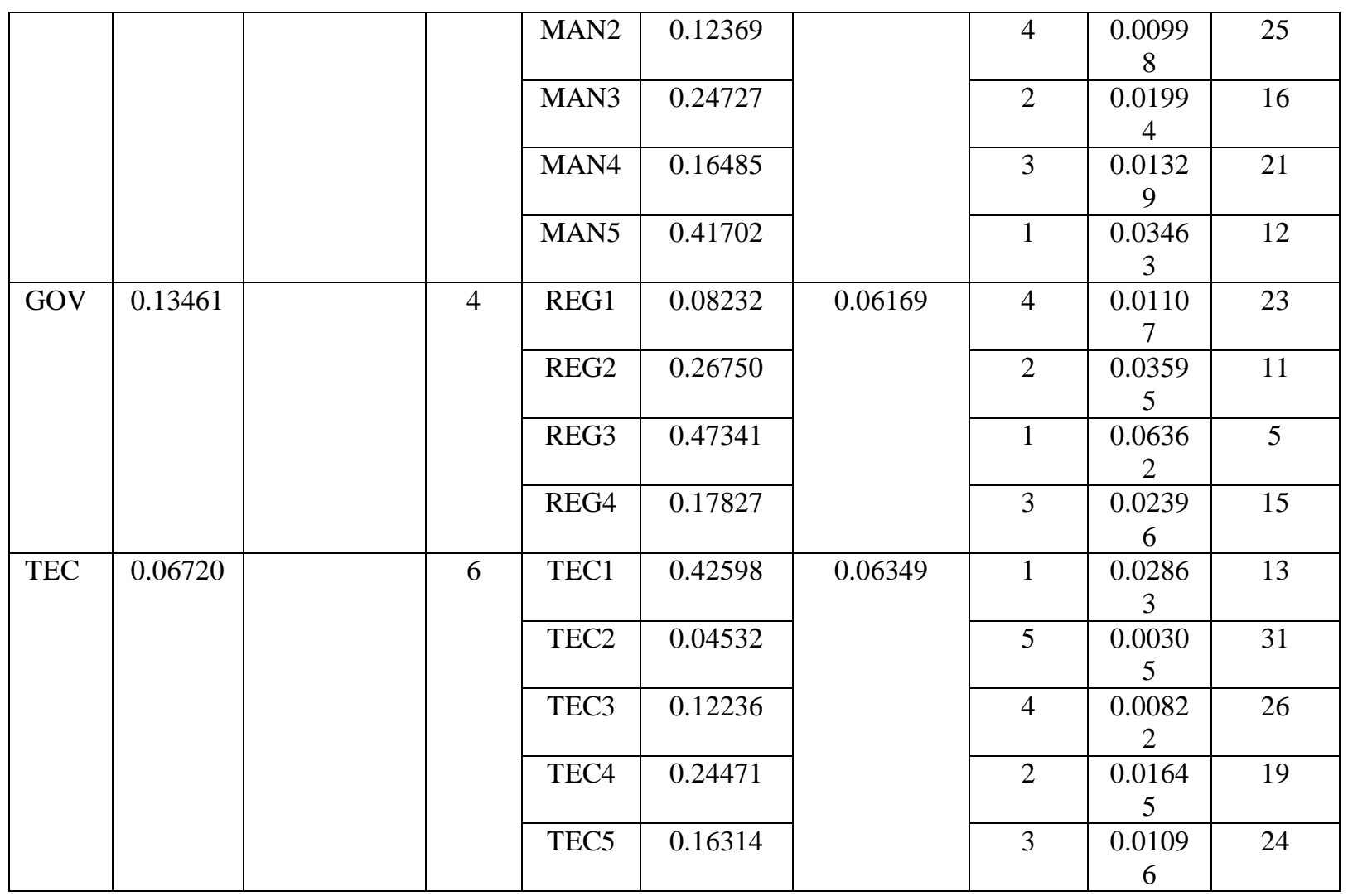

\section{DISCUSSION OF THE RESULTS}

\section{Retailing risk (RET)}

The study reveals that retailing risk is the best (most critical) risk group among the seven identified critical ICSC management risks. Many factors are enlarging the risks in the ICSC retailing point. These factors must be highlighted for successfully performing the ICSC management in current vigorous worldwide business. Retailing risk directly influences expenses and brand image. In this group, the ranking of the sub-risks with practical alleviation strategies are as follows:

(1) Inappropriate separation for the Halal and haram clothing products causing crosscontamination and product-status shift from Halal to haram (RET4); can be addressed by providing dedicated display racks in the showroom unique only for Islamic clothes and shoes to avoid cross-pollution from haram clothing products such as leather bags/shoes made of pigskin.

(2) Demand unpredictability of the Islamic clothing goods (RET3); can be mitigated by building a better relationship with consumers, improving the informationsharing regarding the values of Islamic clothing goods, and investigating situations outside its other business players/rivals and consumers.

(3) The swiftly changing clothing trend (RET1); can be alleviated by increasing the marketing speed, cutting product life cycles, and setting up better selling networks such as using an online marketplace than an offline store. 
(4) Inadequate qualification/skills of salespersons in the company (RET2): can be reduced by presenting a routine and applicable skill-development training platform to develop salespersons' competencies in selling Islamic clothing goods.

\section{Producing risk (PRO)}

Producing risk is the second-best key risk group among ICSC management's confirmed vital risks. Many factors are enlarging the risks in the ICSC producing point. This group's sub-risks based on their ranking and with relevant alleviation approaches are in this manner:

(1) Joint services (here: scissors, cutting machines, sewing machines, and storage) that cause the cross-pollution between Halal and haram clothing products PRO3; can be alleviated by implementing separated services for the Halal and non-Halal goods and washing equipment regularly and adequately before switching the Halal and haram goods, as recommended by Tieman (2017).

(2) The less- advanced design models/ideas for Islamic clothing products (PRO4); can be controlled by investigating the clothing market progress, designing clothes and footwear that are innovative, creating the all-season designs of Islamic clothing products, and hiring very inventive clothing designers.

(3) Inadequate machines, equipment, and facilities for producing Islamic clothing products (PRO2); can be managed with suitable maintenance methods, e.g., preventive equipment maintenance and substitute machinery use for machine failures, as Mangla et al. (2015) suggest.

(4) Improper packing, e.g., the risk of using non-Halal packing materials in the packing process of Islamic clothing products (PRO1), can be tackled by employing Halal packing resources and dependable packaging service Islamic clothing goods.

(5) Errors in clothing manufacture, e.g., pattern-cutting faults causing higher costs (PRO5), can be mitigated by an operative training program for workers and adopting advanced technologies to avoid human errors.

\section{Resourcing risk (RES)}

Resourcing is the first stage of any supply chain, including ICSC, which influences the subsequent stages such as producing and retailing activities. This critical risk ranks number three among the seven critical risks in the ICSC and consists of six sub-risks. The ranking of this group's sub-risks and practical strategies to mitigate those sub-risks are as follows:

(1) Low quality, unclean, impure, and unhygienic raw materials (RES6); can be reduced by a partnership with high-quality suppliers (not low-cost suppliers) that can present high-quality Halal fabrics/cotton/leathers and expanding the attentiveness of supplier and preliminary manufacturer regarding the purity and hygiene.

(2) The shortage of Halal fabrics that can cause the use of unlawful materials to make clothing (RES4); can be controlled by taking on numerous substitutions for these resources in the Halal space, e.g., substituting Halal cow leather with artificial leather to prevent haram leather (pigskin/ unlawful animal skin).

(3) The dearth of supply partners providing Halal resources (RES5); can be managed by publicizing Halal brands globally, inviting new suppliers to apply Halal schemes, and intensifying Halal suppliers' convenience. 
(4) Insufficient knowledge of fabrics due to the unreliable sources of fabrics or not given by the supplier RES2; can be handled by assimilating an effective traceability structure throughout ICSC.

(5) Poor-quality supply partners: i.e., postponements, order completion not in compliance, and slow delivery time (RES1); can be mitigated by regular guidance of quality preservation for the suppliers and adopting the qualified suppliers international market.

(6) The insolvencies of primary supply partners, disrupting the firm's operation (RES3), can be alleviated by executing some procurement/sourcing plans and expanding suppliers' flexibility.

\section{Regulation risk (REG)}

Regulation risk is the fourth critical risk in the ICSC, comprising four sub-risks. The ranking of these sub-risks and the efficient approaches to control them include:

(1) The government's restriction by-law on the Halal industry, including the Islamic clothing industry (REG3), can be alleviated by adopting flexibility and agile/adaptable instruments for ICSC processes and planned corporate operations.

(2) The absence of government funding for Islamic clothing products (REG2); can be addressed by building mutual partnerships with Halal-industry alliances in national and international contexts.

(3) False Halal logo of the goods issued by manufacturers or non-reliable Halal certification bodies (REG4); can be controlled by disciplining the unions that execute these illegal doings and increasing public attentiveness. Here the government must recognize false Halal certification unions and issue a regulation with removing the unlawful operations.

(4) Many Halal certification organizations trigger misperceptions among customers about their legitimacy and at times operate as a blockade in international trade (REG1); this can be mitigated by developing the synchronized Halal certification unions Othman et al. (2016) recommend.

\section{Management risk (MAN)}

Management is a vital part of supply chain operations; in this study, this critical risk ranks fifth among the confirmed seven key risks that shape the ICSC risk management. This critical risk has five sub-risks, of which ranking and correlated mitigation tactics are as follows:

(1) Unsuccessful management policies to implement the ICSC scheme (MAN5); can be addressed by collecting trustworthy information regarding the Islamic clothing trade, building constructive public insights concerning Islamic/Halal clothing, and enhancing info about Halal implementations in the firm.

(2) Team-coordination barriers inside the Islamic clothing companies (MAN3); can be reduced by enhancing team communication, supervising target accomplishment, and implementing improved technologies to develop knowledge sharing. 
(3) Managers' lack of dedication to control the ICSC (MAN4); the awareness will enhance organizational commitment for managing the Islamic clothing business's situation and public suggestions of Halal clothing goods' consumption.

(4) The lack of company's focus on handling the growing risks in the ICSC (MAN2); can be mitigated by performing a compelling company culture, increasing responsiveness to risky conditions in the organization activities, and identifying the risks before setting off the assignment, as Dewi et al. (2015) propose.

(5) Unsuccessful demand estimate (MAN1); can be handled by collecting accurate and factual data from the market and discussing the demand forecasting with professional marketers.

\section{Technology risk (TEC)}

Technology risk is the subsequent critical risk that should be considered as it influences most ICSC activities. Below is the ranking of its four sub-risks with relevant management approaches:

(1) Difficulty in analyzing the Halal status of Islamic clothing goods (TEC1); can be mitigated by employing an effective traceability system along the ICSC stages.

(2) Information-flow ineffectiveness among ICSC partners (TEC4); can be lessened by applying the high-tech information system and data exchange, enhancing employees' technological skills, and employing specialists skilled in innovative technology' maintenance.

(3) High budget/expenses for technology adoption (TEC5); can be addressed by the mutual partnership in technology sharing with other Halal clothing business alliances.

(4) Unsatisfactory information sharing (TEC3); can be mitigated by developing trusts among the S.C. associates and employing useful knowledge-sharing technologies.

(5) Deficiency in data integrity, i.e., the lack of actions to deliver the trustworthy information of products to consumers (TEC2), can also be reduced by enhancing trust between ICSC associates and employing innovative technologies (e.g., blockchain) to support information reliability.

\section{Viability risk (VIA)}

The risk linked to the sustainability aspect is also critical for ICSC management. The sub-risks in this group are the least significant among all other risks (e.g., sub-risks in the retailing, producing, and resourcing stages of the supply chain); it is indispensable to include these sub-risks for more successful ICSC control. The sub-risks in this group have rankings and mitigating strategies as follows:

(1) Increasing costs of the Halal fabrics/cotton/leathers for Islamic clothing goods (VIA2); can be mitigated through enlarging the supply of Halal resources for Islamic clothing goods.

(2) Hijab ban/restriction in purchasing and wearing Islamic clothing goods, often for political purposes (VIA4); can be controlled by reinforcing public moral values in the society and enhancing public realization, e.g., the current 'pro-hijab development' in the USA that has supported Islamic clothing market in the country (Hwang \& Kim, 2020). 
(3) Barriers in foreign currency for international trade (VIA1); can be alleviated by the secure monetary scheme.

(4) Inappropriate waste disposal/ recycling practice for leftover products (VIA3); can be handled by setting up the suitable waste disposal/recycling structure and employing returned products to create bioenergy or manures for carbon-based farming sustainable dampening.

(5) Labor-manager disagreement (VIA5); can be controlled by enhancing better contracts between laborers and managers to avoid labor strikes.

\section{CONCLUSION AND IMPLICATIONS}

\section{Conclusion}

The upsurge of Muslim global clothing business has brought a challenging task for the companies and their business partners to guarantee and maintain the implementation of Halal/Islamic principles along the whole stages of the Islamic clothing supply chain (ICSC), from the beginning/resourcing point until the end/consumer point (Sumarliah et al., 2021). ICSC deals with numerous problems such as the inconsistency of Halal principles in clothing, inaccessibility of devoted facilities, Halal fabrics, leathers, and other raw materials make the ICSC more vulnerable than the traditional supply chain. Thus, assessing risks becomes an entire segment of ICSC management to control those issues.

This paper is an initial effort regarding risk assessment in ICSC management. The study uses the Best-Worst method to discover the critical risks and sub-risks in the ICSC. Firstly, the authors verify the risks via a systematic literature review and later categorized them into seven key risks and thirty-four sub-risks based on specialists' responses. Next, those confirmed risks and sub-risks are ranked with the Best-Worst method.

This study's results show that "retailing risk" is the most significant, ensued by "producing risk," "resourcing risk," "regulation risk," "management risk," "technology risk," and "viability risk." The group rankings and general rankings of sub-risks that can develop effective strategies to reduce those sub-risks are established. The top-ranking risk needs heavier priority and attention than other confirmed risks to allow the effectual management of ICSC. The study also provides several mitigation strategies for each confirmed sub-risks to be considered by practitioners and scholars. The results can help the academicians and business leaders select and develop suitable approaches for ICSC management.

\section{Implications}

The study investigates the critical risk groups and the linked sub-risks in ICSC management. The paper provides several practical implications for managing the Halal system in the ICSC. First, it is imperative to assure and maintain Halal integrity in the ICSC as today's consumers are more sophisticated and analytical regarding Islamic products' Halal status, including fashion products. Moreover, the government of Muslim majority countries such as Indonesia has started to oblige every Islamic product, including clothing and textile goods, to implement a Halal logo (Berita Bisnis, 2019), signifying the big customers' demands Halal-certified goods, including clothing products. Consequently, leaders should answer these challenges by evaluating their ICSCs to manage the risks effectively for their 
sustainable business operations. Second, the discovered and confirmed key risks and subrisks in this study can facilitate leaders and managers uncover the risks in their ICSCs. The author expects direct policymakers, industrialists, and practitioners of the ICSC to validate and rate the key risks and sub-risks existent in their ICSCs. The validated risk groups and their linked sub-risks are wide-ranging and can be executed to ICSC management in particular Muslim-populated nations where the Islamic fashion industry is emergent and dominant, for instance, Indonesia, Turkey, Malaysia, and UAE. The ranks of risk groups and sub-risks will enable decision-makers to determine the risk mitigation approaches. Some beneficial suggestions are provided in Part 6 of this study, which can be operated instantly to lessen the risks in their ICSC. Third, the author reports a prerequisite to deal with retailing risk and its related sub-risks of the uppermost significance. Practitioners in the Islamic fashion market can employ this paper's discoveries to inaugurate lessening strategies and advance the ICSC strength.

\section{LIMITATIONS AND FUTURE RESEARCH}

\section{Limitations}

Like other research works, the paper shows limitations which gives spaces for future studies. Firstly, there is a possibility that several risks might not have been included in this study. Therefore, future research can be conducted to discover more inclusive risks. Next, the confirmed critical risk and sub-risks are general and confirmed from OIC countries' perspective. Thus, the subsequent studies can be conducted in a single country where the Islamic clothing industry is emergent and dominant, such as Indonesia, Malaysia, and UAE. Third, this study focuses on only one industry, namely the Islamic clothing industry. In contrast, Islamic industries are broad; they are not limited to the clothing industry and include the Halal food industry, Halal cosmetics industry, Halal pharmaceutical, Islamic banking and finance, and Halal tourism. Hence, it is also essential to identify and mitigate risks in these different and unique Islamic business sectors.

\section{Future Research}

Future studies can investigate these risks in a specific Muslim-majority country. Also, future studies can be done in Muslim-minority countries where the "pro-hijab movement" has been promoted, such as the USA (Hwang \& Kim, 2020), and where many reputable clothing brands created Islamic clothing products such as European countries with their brands Dolce Gabbana, H\&M, and Zara (Sumarliah et al., 2020). The risks' significance in this paper is measured by the Best-Worts method; thus, future research can adopt the Fuzzy number method to deliver sophisticated measures. Other multi-criteria decision-making methods, .e.g. ANP, TOPSIS, and AHP, can also be employed to rank the risks and measure up to this study's findings.

\section{REFERENCES}

Berita Bisnis. (2019, 10 16). Retrieved 08 20, 2020, from CNN Indonesia: https://www.cnnindonesia.com/ekonomi/20191016145608-92-440050/mulai-besoksemua-produk-wajib-bersertifikat-halal 
Textile \& Clothing. (2020). Retrieved 08 20, 2020, from Global Halal Tourism: https://globalhalaltourism.org/cloth_textiles.php

University Rankings. (2020). Retrieved 08 20, 2020, from Top Universities: https://www.topuniversities.com/university-rankings/world-university-rankings/2020

Ali, M., \& Suleiman, N. (2018, 1). Eleven shades of food integrity: A Halal supply chain perspective. Trends in Food Science \& Technology, 71, 216-224.

Ali, M., Mohd Makhbul, Z., Tan, K., \& Ngah, A. (2016). Augmenting Halal food integrity through supply chain integration. Jurnal Pengurusan, 48, 21-31.

Ali, M., Tan, K., Pawar, K., \& Makhbul, Z. $(2014,6)$. Extenuating food integrity risk through supply chain integration: The case of Halal food. Industrial Engineering and Management Systems, 13(2), 154-162.

Ali, M., Zhan, Y., Alam, S., Tse, Y., \& Tan, K. (2017, 9). Food supply chain integrity: The need to go beyond certification. Industrial Management \& Data Systems, 117(8), $1589-1611$.

Alzeer, J., Rieder, U., \& Hadeed, K. (2018). Rational and practical aspects of Halal and Tayyib in the context of food safety. Trends in Food Science and Technology, 71, 264-267.

Badri Ahmadi, H., Kusi-Sarpong, S., \& Rezaei, J. (2017). Assessing the social sustainability of supply chains using the Best Worst Method. Resources, Conservation and Recycling, 126, 99.

Dewi, D., Syairudin, B., \& Nikmah, E. (2015). Risk management in the new product development process for the fashion industry: A case study in the Hijab industry. Procedia Manufacturing, 4, 383-391.

DinarStandard. (2020). State of the global Islamic economy 2019/20 Report. Retrieved 0820 , 2020, from Salaam Gateway: https://www.salaamgateway.com/specialcoverage/SGIE19-

20\#: :text=The\%202019\%2F20\%20State\%20of,faith\%2Dinspired\%20ethical\%20con sumption\%20needs

Dumas, D. (2016, 8). Non-Muslims flock to buy burkinis as French bans raise the profile of the modest swimwear style. Retrieved from SMH: https://www.smh.com.au/lifestyle/nonmuslims-flock-to-buy-burkinis-as-french-bansraise-profile-of-the-modest-swimwear-style-20160819-gqwx95.html

Faisal, M., \& Talib, F. (2016). Implementing traceability in Indian food-supply chains: An interpretive structural modeling approach. Journal of Foodservice Business Research, 19(2), 171-196.

Gupta, H., \& Barua, M. (2018). A novel hybrid multi-criteria method for supplier selection among SMEs on the basis of innovation ability. International Journal of Logistics Research and Applications, 21(3), 1-23.

Haleem, A., \& Khan, M. (2017). Towards successful adoption of Halal logistics and its implications for the stakeholders. British Food Journal, 119(7), 1592-1605.

Haleem, A., Khan, M., \& Khan, S. (2020). Conceptualizing a framework linking Halal supply chain management with sustainability: An India-centric study. Journal of Islamic Marketing.

Haleem, A., Khan, S., \& Khan, M. (2019). Traceability implementation in food supply chain: A grey-DEMATEL approach. Information Processing in Agriculture, 6(3).

Hwang, C., \& Kim, T. (2020). Muslim women's purchasing behaviors toward modest activewear in the United States. Clothing and Textiles Research Journal, $0887302 X 2092657$.

Isfianadewi, D., Pambudi, A., Siswanti, Y., Surjanti, J., \& Muafi. (2018). Risk mitigation in design \& production of the new product development process (case study: Hijab 
company in Yogyakarta). International Journal of Mechanical Engineering and Technology, 9(6), 57-66.

Ismail, W., Othman, M., Rahman, R., Kamarulzaman, N., \& Rahman, S. (2016). Halal Malaysia logo or brand: The hidden gap. Procedia Economics and Finance, 37, 254261.

Khan, M., \& Haleem, A. (2016). Understanding " Halal" and " Halal certification \& accreditation system " - A brief review. Saudi Journal of Business and Management Studies, 1(1), 32-42.

Khan, M., Haleem, A., \& Khan, S. (2018). Defining Halal supply chain management. Supply Chain Forum, 19(2), 122-131.

Khan, S., Haleem, A., \& Khan, M. (2021, 1). Assessment of risk in the management of Halal supply chain using fuzzy BWM method. Supply Chain Forum: An International Journal, 22(1), 1-17.

Krejcie, R., \& Morgan, D. (1970). Determining sample size for research activities. Educational and Psychological Measurement, 30(3), 607-610.

Mangla, S., Kumar, P., \& Barua, M. (2015, 11). Risk analysis in the green supply chain using fuzzy AHP approach: A case study. Resources, Conservation and Recycling, 104, 375-390.

Moazzam, M. (2020). 10 Muslim-Owned Fashion and Beauty Brands You Need to Know. Retrieved from Allure: https://www.allure.com/gallery/muslim-owned-fashionbeauty-brands

Neio Demirci, M., Soon, J., \& Wallace, C. (2016). Positioning food safety in Halal assurance. Food Control, 70, 257-270.

Ngah, A., Zainuddin, Y., \& Thurasamy, R. $(2015,9)$. Barriers and enablers in adopting Halal warehousing. Journal of Islamic Marketing, 6(3), 49-70.

Othman, B., Shaarani, S., \& Bahron, A. (2016, 8). Evaluation of knowledge, Halal quality assurance practices, and commitment among food industries in Malaysia. British Food Journal, 118(8), 2034-2052.

Pamučar, D., Petrović, I., \& Ćirović, G. (2018). Modification of the Best-Worst and MABAC methods: A novel approach based on interval-valued fuzzy-rough numbers. Expert Systems with Applications, 91, 89-106.

Prakash, C., \& Barua, M. (2016). An analysis of the integrated robust hybrid model for thirdparty reverse logistics partner selection under a fuzzy environment. Resources, Conservation and Recycling, 108, 63-81.

Religion by country 2021. (n.d.). Retrieved 01 05, 2021, from World Population Review: https://worldpopulationreview.com/country-rankings/religion-by-country

Rezaei, J. (2015). Best-worst multi-criteria decision-making method. Omega (United Kingdom), 53, 4957.

Rezaei, J. $(2016,10)$. Best-worst multi-criteria decision-making method: Some properties and a linear model. Omega, 64, 126-130.

Rezaei, J., Kothadiya, O., Tavasszy, L., \& Kroesen, M. (2018). Quality assessment of airline baggage handling systems using SERVQUAL and BWM. Tourism Management, 66, 85-93.

Seth, S. (2016). How Islamic is the business of modest fashion? Retrieved from Salaam Gateway: https://www.salaamgateway.com/story/how-islamic-is-the-business-ofmodest-fashion

Shahbaz Khan, M., Mohd Imran Khan, M., Abid Haleem, D., Mohd Shuaib, M., Khan, S., Imran Khan, M., et al. (2018). Selection of traceable technology in the food supply chain. IOP Conference Series: Materials Science and Engineering, 404(1), 012010. 
Soon, J., Chandia, M., \& Regenstein, J. $(2017,1)$. Halal integrity in the food supply chain. British Food Journal, 119(1), 39-51.

Sumarliah, E., Li, T., \& Wang, B. (2020, 2). Hijab fashion supply chain: a theoretical framework traversing consumers' knowledge and purchase intention., 308, p. 04004.

Sumarliah, E., Li, T., Wang, B., Moosa, A., \& Sackey, I. (2021). The impact of customer Halal supply chain knowledge on customer Halal fashion purchase intention. Information Resources Management Journal, 34(3).

Talib, M., \& Hamid, A. (2015). Motivations and limitations in implementing Halal food certification: A Pareto analysis. British Food Journal, 117(11), 2664-2705.

Tan, K., Ali, M., Makhbul, Z., \& Ismail, A. (2017, 3). The impact of external integration on Halal food integrity. Supply Chain Management: An International Journal, 22(2), 186-199.

Tieman, M. (2011, 6). The application of Halal in supply chain management: in-depth interviews. Journal of Islamic Marketing, 2(2), 186-195.

Tieman, M. (2017, 9). Halal risk management: combining robustness and resilience. Journal of Islamic Marketing, 8(3), 461-475.

Tieman, M., van der Vorst, J., \& Ghazali, M. (2012). Principles in Halal supply chain management. Journal of Islamic Marketing, 3(3), 217-243.

Top 18 Hijab Brands - Best Brands for Hijabis to Try this Year. (n.d.). Retrieved from Branded Girls: https://www.brandedgirls.com/top-hijab-brands-best-brands-forhijabis/

van der Spiegel, M., van der Fels-Klerx, H., Sterrenburg, P., van Ruth, S., Scholtens-Toma, I., \& Kok, E. (2012, 10). Halal assurance in food supply chains: Verification of Halal certificates using audits and laboratory analysis. Trends in Food Science \& Technology, 27(2), 109-119.

Vishnupriyan, J., \& Manoharan, P. (2018). Multi-criteria decision analysis for renewable energy integration: A southern India focus. Renewable Energy, 121, 474-488.

Wahyuni, H., Vanany, I., Ciptomulyono, U., \& Purnomo, J. (2020, 10). Integrated risk to food safety and Halal using a Bayesian Network model. Supply Chain Forum: An International Journal, 21(4), 260-273.

Wu, T., \& Blackhurst, J. (2009). Managing supply chain risk and vulnerability (Eds ed.). (T. Wu, \& J. Blackhurst, Eds.) London: Springer London.

Zailani, S., Arrifin, Z., Wahid, N., Othman, R., \& Fernando, Y. (2010). Halal traceability and Halal tracking systems in strengthening Halal food supply chain for the food industry in Malaysia (A Review). Journal of Food Technology, 8(3), 74-81. 